$\begin{array}{ll} & \text { Preprints are preliminary reports that have not undergone peer review. } \\ \text { Research Square } & \text { They should not be considered conclusive, used to inform clinical practice, } \\ \text { or referenced by the media as validated information. }\end{array}$

\title{
Lipid Production from Crude Glycerol by Newly Isolated Oleaginous Yeasts: Strain Selection, Molecular Identification and fatty acid analysis
}

Derya Berikten ( $\nabla$ derya.berikten@ksbu.edu.tr)

Kütahya Health Sciences University https://orcid.org/0000-0002-8672-4813

Emir Zafer Hosgun

Eskişehir Technical University: Eskisehir Teknik Universitesi

Ayşe Gökdal Otuzbiroğlu

Eskişehir Technical University

Berrin Bozan

Eskişehir Technical University

Merih Kıvanç

Eskişehir Technical University

Research Article

Keywords: Oleaginous yeasts, Biodiesel, Microbial lipid, Crude glycerol, Screening

Posted Date: February 19th, 2021

DOI: https://doi.org/10.21203/rs.3.rs-224193/v1

License: @) (7) This work is licensed under a Creative Commons Attribution 4.0 International License. Read Full License

Version of Record: A version of this preprint was published at Waste and Biomass Valorization on March 4th, 2021. See the published version at https://doi.org/10.1007/s12649-021-01405-1. 


\section{Abstract}

Biodiesel is a renewable alternative fuel and glycerol as a main byproduct of the manufacturing process. Lipids could be produced from crude glycerol by using yeasts. The ability of 107 yeast strains to utilize glycerol was screened and 92 of these were selected. 60 strains were determined as a potential for lipid production by Sudan Black B staining. After secondary screening 25 of them showed specific growth rates (OD 600), high biomass production and lipid content. These strains were identified as Pichia cactophila, P. fermentans, P. anomala, Rhodotorula mucilaginosa, R. dairenensis, Clavispora lusitaniae, Saccharomyces cerevisiae, Wickerhamomyces anomalus, Candida glabrata, C. inconspicua, C. albicans, Yarrowia lipolytica with molecular identifications based on ITS and D1/D2 26S rDNA sequences. The results showed that $P$. cactophila accumulated lipid up to 64.94\%, the highest lipid content. C16:0, C18:0, C18:1 and C18:2 essential fatty acids for biodiesel production were detected by GC-MS in the lipids accumulated by all strains. P. cactophila and C. Iusitaniae were reported for the first time as lipid-producing yeasts. The results suggest that selected 25 isolates have the ability to grow on crude glycerol and especially $P$. cactophila produce lipid that has potential use as a feedstock for second generation biodiesel production.

\section{Statement Of Novelty}

In this study, two step screening was used for determining oleaginous yeasts which metabolize crude glycerol. Screening of new oleaginous microorganisms was important to find alternative sources of microorganisms to be used in biodiesel production. The 25 tested strains were potentially lipid-producer and generating more than $25.55 \%$ (wt/wt) lipids. Crude glycerol, a by-product of the biodiesel industry, was consumed mainly by Pichia cactophila and it was showed the highest yield (64.94\%). Hence, the novelty of this study is for the first time Pichia cactophila and Clavispora lusitaniae being categorized as an oleaginous yeast. Palmitic, stearic, oleic and linoleic acid, essential fatty acids were produced by all strains.

\section{Introduction}

Biodiesel has attracted attention as an alternative and environmentally friendly fuel because of its low toxicity, biodegradability, and low concentrations of small particulate matter and $\mathrm{SO}_{2}$ in exhaust gas when used in motor vehicles [1]. It is made from various vegetable oils or renewable biomass with short chain alcohol through transesterification. The oil raw material used for biodiesel production must absolutely compete with the food supply chain that brings food against the debate on biofuels versus food [2]. Biodiesel production is a process in which $10 \%$ crude glycerol is separated from the triacylglycerides in fats or vegetable oils [3].

Crude glycerol has some impurities such as methanol and potassium so crude glycerol processes limited value. Conversion of crude glycerol to specific products by chemical transformation may provide disadvantages such as low product specificity, high energy input and pretreatment requirements [4]. Crude glycerol has been employed as a substrate to obtain value added products such as 1,3-propanediol, lipids (SCO-single cell oils), citric acid, erythritol, succinic acid, butanol, ethanol, and hydrogen by bacteria, yeast, fungal or algal species $[4,5,6]$.

Oleaginous microorganisms are known to accumulate lipids to more than $20 \%$ of their total cell dry weight. Single cell oil (SCO) refers to the lipids produced by bacteria, yeasts, moulds and algae. Microorganisms meet the increasing oil demand for biodiesel production due to the structure similar to vegetable oils and fatty acid compositions. Microbial oil production has many positive factors such as short life cycle, less labor requirement, less space usage, no impact

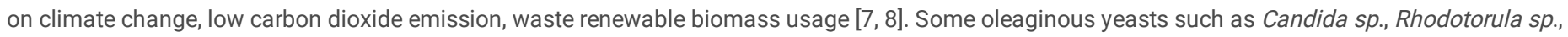
Rhodosporidium sp., Yarrowia sp., Trichosporon sp. and Cryptococcus sp. accumulate lipids to a level corresponding to $40 \%$ of their biomass. However, during growth on nutrient-limited media such as fats, vegetable oils, and glycerol may accumulate lipids up to $70 \%$ of their biomass [6, 9, 10].

In recent years, interest in natural new yeasts isolated from different environments, has increased considerably in various biological production processes, including lipid production. Because they have important features such as genetic stability, environmental adaptation and special biotechnological attributes $[11,12,13,14]$. Furthermore, the interesting results obtained with these wild-type yeasts in various fermentation processes suggest that screening studies with newly isolated yeasts are very important in terms of lipid production. There are several articles published in the past several years with focus on lipid accumulation from glycerol and crude glycerol by oleaginous yeasts but limited studies are available on comparative screening of newly isolated oleaginous yeast strains.

In this paper, two step screening of one hundred and seven yeast strains for the ability to grow and accumulate lipids in media containing glycerol as the sole carbon source were done. Twenty five yeast strains which grew the best were further tested for growth, biomass production, lipid content, fatty acid composition and identified molecular methods based on ITS and D1/D2 26S rDNA sequences.

\section{Materials And Methods}

\section{Microorganisms}

One hundred and seven yeast strains previously isolated from boza (which is a traditional fermented Turkish drink) were used in the study. For isolation of yeasts, Dichloran Rose Bengal Chloramphenicol Agar and Rose Bengal Chloramphenicol Agar (DRBCA, RBCA, Oxoid CM727, Basingstoke, UK) was used and incubated at $25^{\circ} \mathrm{C}$ for $4-5$ days [15]. The yeast strains were maintained on YPD agar slant [6] and stored at $4{ }^{\circ} \mathrm{C}$ before use.

\section{Screening of oleaginous yeast}

Two step screens were performed by using glycerol as the sole carbon source. 
In the first screen, the yeast isolates were screened for their lipid-producing abilities on glycerol plates by qualitative analysis with the Sudan Black B staining technique [16]. The fresh yeast cultures were streaked onto glycerol plates [in g/L: peptone 20, yeast extract 20 , commercial glycerol 30 (purity $85 \%$ ) or crude glycerol 30]. After the petri dishes were incubated at $30^{\circ} \mathrm{C}$ for two days, yeast isolates growing in both media or in crude glycerol medium were selected.

Selected yeast cultures were stained with Sudan Black B technique. Prepared slides were observed under a phase contrast microscope on oil immersion. The presence of blue or greyish coloured fat globules within the cell was a positive result and the yeast strains showing that were selected for the second screen.

In the second screen, a loopful of cells from colonies on YPD agar plates were transferred to YPD broth (inoculum medium) and were incubated at $25^{\circ} \mathrm{C}$ with shaking at $150 \mathrm{rpm}$ for $72 \mathrm{~h}$. One $\mathrm{mL}$ of the prepared inoculum cultures was added to $20 \mathrm{~mL}$ of the medium containing $40 \mathrm{~g} / \mathrm{L}$ crude glycerol, $20 \mathrm{~g} / \mathrm{L}$ peptone, $20 \mathrm{~g} / \mathrm{L}$ yeast extract and $\mathrm{C} / \mathrm{N}$ ratio $\sim 2,28$. The mixtures were incubated for $72 \mathrm{~h}$ at $25^{\circ} \mathrm{C}$ with shaking at $150 \mathrm{rpm}$. Growth of the cultures were monitored by OD600 measurements of directly optical densities against the medium blank at $600 \mathrm{~nm}$.

The best developing species were selected for cell dry weight, lipid content and fatty acid composition determination. Also, these species were identified. All chemicals used in the experiments were purchased from Merck Millipore.

\section{Determination of yeast dry weight}

Two $\mathrm{mL}$ of the cultures were centrifuged at $5000 \times \mathrm{g}$ for $5 \mathrm{~min}$. The pellet was washed twice with $5 \mathrm{~mL}$ of distilled water and dried at $60{ }^{\circ} \mathrm{C}$ until constant weight (typically $24 \mathrm{~h}$ ). The dry cell weight was determined gravimetrically [17].

\section{Extraction of lipid compounds}

Total lipids were extracted from whole yeast cells by the method of Pan et al [17]. This is a fast procedure allowing complete lipid extraction. Briefly, 50-mL cell cultures were centrifuged at $5000 \mathrm{xg}$ for $5 \mathrm{~min}$. The yeast pellets were washed twice with distilled water, then added into $10 \mathrm{~mL}$ of $4 \mathrm{M} \mathrm{HCl}$, and incubated at 60 ${ }^{\circ} \mathrm{C}$ for 1 to $2 \mathrm{~h}$. Then the acid-hydrolysed pellets were stirred with $20 \mathrm{~mL}$ of chloroform/methanol solution (1:1) at room temperature for 2 to $3 \mathrm{~h}$. The mixtures were centrifuged at $2000 \mathrm{xg}$ for $5 \mathrm{~min}$ to separate the aqueous and organic phases. The lower phases containing lipids were recovered with a Pasteur pipette, and evaporated until dried. The dry lipid weight was determined gravimetrically [17].

\section{Determination of glycerol concentration}

The concentration of residual glycerol in the culture medium was analysed by high-performance liquid chromatography (HPLC), which was mainly equipped with a Bio-Rad Aminex HPX-87H column $(300 \mathrm{~mm} \times 7.8 \mathrm{~mm})$, and a refractive index detector. The analytical column was operated at $60^{\circ} \mathrm{C}$ with $0.2 \mu \mathrm{m}$ filtered $0.005 \mathrm{M} \mathrm{H}_{2} \mathrm{SO}_{4}$ solution as the mobile phase. The mobile phase flow rate was $0.6 \mathrm{ml} / \mathrm{min}$ [18].

\section{Fatty acid composition determination}

Fatty acid compositions of oil samples were determined using a modified fatty acid methyl esters (FAME) method. The oil extracts obtained were transmethylated to FAME by heating $\left(90^{\circ} \mathrm{C}\right.$ for $45 \mathrm{~min}$ ) with a mixture of $35 \%$ (vol/vol) $\mathrm{BF}_{3} / \mathrm{MeOH}(12 \% \mathrm{BF} 3 / \mathrm{MeOH}), 45 \%(\mathrm{vol} / \mathrm{vol}) \mathrm{MeOH}$, and $29 \%$ (vol/vol) hexane [16]. The FAME was then analyzed by GC/MS (Agilent 7820A/5977EMSD). The system was equipped with an autosampler and an MS detector. Helium was used as the carrier gas. The FAME were separated on a capillary column $(100 \mathrm{~m} \times 0.20 \mathrm{~mm}$, HP-88, Agilent J\&W Column) with the film thickness of $0.25 \mu \mathrm{m}$. The detector temperature was set at $230^{\circ} \mathrm{C}$. Initial column temperature was $120^{\circ} \mathrm{C}$ for $1 \mathrm{~min}$ and increased to $175^{\circ} \mathrm{C}$ at the rate of $10^{\circ} \mathrm{C} / \mathrm{min}$, held at $175^{\circ} \mathrm{C}$ for $10 \mathrm{~min}$, then increased to $210^{\circ} \mathrm{C}$ at the rate of $5^{\circ} \mathrm{C} / \mathrm{min}$ held at $210^{\circ} \mathrm{C}$ for $5 \mathrm{~min}$. and then increased to $230^{\circ} \mathrm{C}$ at the rate of $5^{\circ} \mathrm{C} / \mathrm{min}$ and held for 10 $\min [19]$.

\section{Molecular identification}

Molecular characterization of yeasts, cultures were grown on Yeast Extract Agar prior to DNA extraction. DNAs were isolated by using GE Healthcare genomic DNA purification kit and used for PCR amplification. Internal Transcribed Spacer (ITS-1, 5.8S and ITS-2) regions of the rDNA genes and D1/D2 domain of the $26 \mathrm{~S}$ rDNA genes which were the standard gene regions for molecular identification were amplified by using primers NL1 (5'-GCATATCAATAAGCGGAGGAAAAG3') and NL4 (5'-GGTCCGTGTTTCAAGAGG-3') for D1/D2 region [20] and primers ITS1 (5'-TCCGTAGGTGAACCTGCGG-3') and ITS4 (5'-

GCATATCAATAAGCGGAGGA-3') for ITS region [21]. Then they were sequenced by CEQ 8000 Genetic Analysis System. Obtained sequences in this study were compared with those deposited in the National Center for Biotechnology Information (NCBI) Database by BLAST for identification. The ITS and D1/D2 region sequences of identified yeasts were submitted to GenBank for accession numbers.

\section{Result And Discussion Screening}

One hundred and seven yeast strains previously isolated from boza were tested in YPD medium using commercial glycerol or crude glycerol as carbon source. It was determined that crude glycerol, provided by a private waste oil collection company, showed the following properties: pH 6.9 and purity $70.775 \%$. Ninetytwo strains which could be growing both of the medium or only crude glycerol medium were stained with Sudan black B technique and observed under microscope for the presence of fat globules within the cell. Sixty yeast strains were found positive for showing fat globules within the cell (Fig. 1) and they were selected as potential lipid biomass producers (Table 1). It has been demonstrated that Sudan black B staining technique is a rapid method of screening lipid production. In their work Kitcha and Cheirsilp [16] were determined rapidly whether 889 yeast strains had lipid production ability by Sudan black B technique and they have revealed that 23 isolates are potential lipid producers. 
Table 1

Growth on commercial/crude glycerol and results of staining

\begin{tabular}{|llll|}
\hline Carbon source & \multicolumn{3}{c|}{ Number of yeast strains } \\
\cline { 2 - 4 } & & Growth & \multicolumn{1}{c|}{ Sudan black B staining } \\
& & & \\
\cline { 2 - 4 } & & + & - \\
\hline Crude glycerol & 1 & 1 & 32 \\
\hline Crude glycerol and commercial glycerol & 91 & 59 & no staining \\
\hline Commercial glycerol & 6 & no staining & \\
\hline
\end{tabular}

In the first screening, we performed lipid screening on both crude glycerol and commercial glycerol medium. In the experiments, two separate glycerol's were used to see the differences in metabolizing the crude and commercial glycerol of microorganisms. In general, 107 isolates grew on both glycerol media. Only 6 of them did not grow in crude glycerol and 9 of them did not grow in both (Table 1). Similar to our work previously shown that crude glycerol is a useful waste substrate for lipid production by Yarrowia lipolytica [22, 23] and some other yeasts [5].

Results of the secondary screening, summarized in Fig. 2, show the final OD600 values of the 60 yeasts in a medium containing crude glycerol as carbon source $(40 \mathrm{~g} / \mathrm{l})$. Between the 60 yeast strains tested, $25 \mathrm{grew}$ well and reached final OD600 of nearly 2 Units or up. They were selected for calculation of growth parameters and lipid yield. Good performance was exhibited by isolate 4 that reached final OD600 of 2.74 on the other hand isolate 37 grew most poorly (Fig. 2). Many researches have been done on the microbial conversion of crude glycerol. However, impurities in crude glycerol often negatively affected the success of these processes [24]. Since we are working with a crude glycerol containing higher impurities (purity $70.775 \%$ ) than various publications (14, $22,23 ; 25)$, the selection was made among the isolates by looking at their ability to metabolize crude glycerol in the screening step. Also, in microbial lipid production studies, $\sim 20-100 \mathrm{C} / \mathrm{N}$ ratio has been used because it is known that high $\mathrm{C} / \mathrm{N}$ ratio promotes lipid production in some yeast species [14, 22, 23 , 26]. On the other hand, as we mentioned above, the crude glycerol we used has high impurities for this reason a second stress factor affecting growth due to low nitrogen ratio was not used.

\section{Calculation Of Lipid Yield Parameters And Biomass}

Among 25 isolates, four of them (1, 4, 6 and 18) gave high lipid yield with lipid content higher $55 \%$ when grown in broth medium containing crude glycerol for $72 \mathrm{~h}$. Table 2 shows biomass and lipid yield parameters of all strains. The lowest amount of lipid yield obtained from 25 yeast isolates selected by firstscreening $(25,55 \%)$ was indicative of the accuracy of the pre-screening. It was determined that isolate 1 gave highest lipid content and highest lipid yield up to $64.94 \%$ and $7.14 \mathrm{~g} / \mathrm{L}$, respectively (11 mg/mL of biomass). High lipid accumulation and also high lipid coefficient in crude glycerol media, isolate $1 \mathrm{was}$ selected for the further studies. 
Table 2

Charaterization of lipid production of yeasts and statistical data

\begin{tabular}{|c|c|c|c|c|c|}
\hline Isolate number & Biomass (g/L) & Lipid yield (g/L) & Lipid \% & Glycerol utilized (g/L) & Lipid coefficient (g lipid/g glycerol) \\
\hline 1 & $11 \pm 0.55$ & $7.14 \pm 0.07$ & $64.94 \pm 0.65$ & $17.49 \pm 0.35$ & $0.409 \pm 0.004$ \\
\hline 2 & $9 \pm 0.36$ & $3.89 \pm 0.12$ & $43.17 \pm 1.30$ & $12.17 \pm 0.49$ & $0.319 \pm 0.010$ \\
\hline 3 & $11 \pm 0.44$ & $5.49 \pm 0.22$ & $49.87 \pm 1.99$ & $27.75 \pm 0.83$ & $0.197 \pm 0.008$ \\
\hline 4 & $9 \pm 0.63$ & $5.54 \pm 0.22$ & $61.59 \pm 2.46$ & $27.86 \pm 1.39$ & $0.199 \pm 0.009$ \\
\hline 5 & $9.5 \pm 1.14$ & $4.34 \pm 0.30$ & $45.71 \pm 3.20$ & $8.48 \pm 0.09$ & $0.512 \pm 0.033$ \\
\hline 6 & $11.5 \pm 0.69$ & $6.34 \pm 0.06$ & $55.16 \pm 0.55$ & $26.24 \pm 0.79$ & $0.242 \pm 0.002$ \\
\hline 7 & $10.5 \pm 0.53$ & $4.40 \pm 0.13$ & $41.9 \pm 1.26$ & $27.82 \pm 1.39$ & $0.158 \pm 0.005$ \\
\hline 8 & $15.5 \pm 0.47$ & $4.97 \pm 0.20$ & $32.07 \pm 1.28$ & $26.36 \pm 0.53$ & $0.189 \pm 0.007$ \\
\hline 9 & $13 \pm 0.65$ & $5.26 \pm 0.16$ & $40.44 \pm 1.21$ & $20.16 \pm 0.81$ & $0.261 \pm 0.008$ \\
\hline 10 & $11 \pm 0.99$ & $5.72 \pm 0.11$ & $51.95 \pm 1.04$ & $27.81 \pm 0.56$ & $0.206 \pm 0.004$ \\
\hline 11 & $12 \pm 0.48$ & $5.89 \pm 0.12$ & $49.05 \pm 0.98$ & $27.85 \pm 1.11$ & $0.211 \pm 0.005$ \\
\hline 12 & $8.5 \pm 0.85$ & $2.17 \pm 0.07$ & $25.55 \pm 0.77$ & $5.37 \pm 0.06$ & $0.404 \pm 0.012$ \\
\hline 16 & $12.5 \pm 0.37$ & $5.54 \pm 0.17$ & $44.34 \pm 1.33$ & $27.6 \pm 0.83$ & $0.201 \pm 0.006$ \\
\hline 18 & $10 \pm 0.7$ & $5.77 \pm 0.12$ & $57.71 \pm 1.15$ & $27.87 \pm 1.39$ & $0.207 \pm 0.004$ \\
\hline 26 & $11.5 \pm 0.35$ & $5.77 \pm 0.23$ & $50.19 \pm 2.00$ & $27.87 \pm 0.56$ & $0.207 \pm 0.008$ \\
\hline 30 & $11.5 \pm 0.23$ & $5.31 \pm 0.32$ & $46.21 \pm 2.77$ & $27.42 \pm 1.10$ & $0.194 \pm 0.011$ \\
\hline 41 & $9.5 \pm 0.86$ & $5.09 \pm 0.05$ & $53.53 \pm 0.54$ & $27.87 \pm 1.39$ & $0.183 \pm 0.002$ \\
\hline 63 & $11.5 \pm 0.46$ & $5.54 \pm 0.11$ & $48.19 \pm 0.95$ & $27.88 \pm 0.83$ & $0.199 \pm 0.004$ \\
\hline $68-1$ & $12.5 \pm 0.38$ & $6.17 \pm 0.09$ & $49.37 \pm 0.75$ & $27.61 \pm 0.28$ & $0.224 \pm 0.003$ \\
\hline $68-2$ & $11.5 \pm 0.92$ & $5.83 \pm 0.06$ & $50.68 \pm 0.51$ & $27.71 \pm 0.28$ & $0.210 \pm 0.002$ \\
\hline 82 & $12.5 \pm 0.25$ & $5.54 \pm 0.17$ & $44.34 \pm 1.33$ & $27.55 \pm 1.38$ & $0.201 \pm 0.006$ \\
\hline 84 & $11 \pm 0.33$ & $4.97 \pm 0.20$ & $45.19 \pm 1.81$ & $21.57 \pm 0.64$ & $0.231 \pm 0.009$ \\
\hline $95-1$ & $11 \pm 0.66$ & $4.74 \pm 0.14$ & $43.12 \pm 1.29$ & $27.87 \pm 1.11$ & $0.170 \pm 0.005$ \\
\hline $95-2$ & $10 \pm 0.8$ & $4.51 \pm 0.09$ & $45.14 \pm 0.90$ & $27.88 \pm 0.56$ & $0.162 \pm 0.003$ \\
\hline 110 & $10 \pm 0.6$ & $5.49 \pm 0.06$ & $54.86 \pm 0.55$ & $27.83 \pm 0.45$ & $0.197 \pm 0.002$ \\
\hline
\end{tabular}

After 72 hours of incubation, the analysis of residual crude glycerol is performed for calculation of lipid coefficient. Yeast isolates were not utilized glycerol completely. It was thought that the accumulated lipids in the yeast cells were not used for lipid-free biomass synthesis because yeasts do not use their stored lipids before the run out of extracellular carbon supply $[27,28,29]$.

For indicating further availability of using strains selected in this study for single cell oil production from crude glycerol, lipid production results of this study were compared with other oleaginous microorganisms using crude glycerol as the sole carbon source. The biomass, lipid content and lipid yield of Yarrowia lipolytica ATCC 20460 after fermentation were $11.6 \mathrm{~g} / \mathrm{L}, 31 \%$ and $3.6 \mathrm{~g} / \mathrm{L}$, respectively [30]. The biomass, lipid content and lipid yield of Cryptococcus curvatus ATCC 20509 after fermentation were $29.2 \mathrm{~g} / \mathrm{L}, 26.0 \%$ and $7.7 \mathrm{~g} / \mathrm{L}$, respectively [31]. The biomass, lipid content and lipid yield of Kodamaea ohmeri BY4-523 and Trichosporanoides spathulata JU4-57 after fermentation were $10.3 \mathrm{~g} / \mathrm{L}, 53.0 \%, 5.5 \mathrm{~g} / \mathrm{L}$ and $17.0 \mathrm{~g} / \mathrm{L}, 43 \%, 7.4 \mathrm{~g} / \mathrm{L}$, respectively [32]. The biomass, lipid content, lipid yield and lipid coefficient of Rhodotorula g/utinis TISTR 5159 were $8.17 \mathrm{~g} / \mathrm{L}, 53 \%, 4.3 \mathrm{~g} / \mathrm{L}$, and 7\%, respectively [33]. The biomass, lipid content, lipid yield and lipid coefficient of Mortierella isabellina were $6.2 \mathrm{~g} / \mathrm{L}, 53 \%, 3.3 \mathrm{~g} / \mathrm{L}$ and $12 \%$ respectively [34]. The biomass, lipid content, lipid yield, and lipid coefficient of Trichosporon fermentans and Trichosporon cutaneum after 8-day fermentation were $16.0 \mathrm{~g} / \mathrm{L}, 32.4 \%, 5.2 \mathrm{~g} / \mathrm{L}, 16.5 \%$, and $17.4 \mathrm{~g} / \mathrm{L}, 32.2 \%, 5.6$ $\mathrm{g} / \mathrm{L}, 17.0 \%$, respectively [35]. Maximum lipid content of lipid-engineered Yarrowia lipolytica strain JMY4086 after continuous culture with molasses and crude glycerol under different oxygenation conditions was 31\% [23]. Biomass and lipid yield parameters of selected 25 isolates in this study by two step screening were moderate or higher than strains above, exhibiting that strains in current study were encouraging strains for single cell oil production using crude glycerol as the sole carbon source.

\section{Fatty Acid Compositions}

Lipid samples produced by fermentation on crude glycerol were analysed by GC/MS. Percentages of total fatty acids were shown in Table 3. The fatty acid contents of fatty yeasts are generally known to consist of long chain fatty acids such as C16 and C18 [36]. Lipids of selected 25 oleaginous fungi were composed mainly of long-chain fatty acids with 16 and 18 carbon atoms. Main fatty acids of microbial lipids are an important indicator that whether it can be used for biodiesel production. For the quality of biodiesel and optimum fuel properties Fatty acid composition is quite important. Increasing the chain length 
of fatty acids increases the cetane number, combustion temperature, melting point and viscosity of clean oil compounds of biodiesel. Furthermore, the high amount of oleic acid in fatty acid content has a positive effect on biodiesel properties [36]. Presence of C16:0, C18:0, C18:1 and C18:2 fatty acids were detected by GC-MS. FAME analysis of yeast strains are relevant from a biodiesel standpoint and also to discriminate closely related strains. The total unsaturated fatty acids, oleic acid and linoleic acid similar to that of plant oils were $>50 \%$ of microbial oils except isolate 7 . Knothe [37] was reported that the best fatty acid composition for biodiesel production is palmitic acid (C16:0), stearic acid (C18:0), oleic acid (C18:1), linoleic acid (C18:2) and linolenic acid (C18:3). This indicates that lipids from oleaginous yeasts selected in this study have potential use as a feedstock for second generation biodiesel production. These fatty acids were reported by Kumar et al. for lipid production from municipal waste in the glycerol medium, and they also concluded that these fatty acids are suitable for biodiesel production [25].

Table 3

Percentages of total fatty acids from selected isolates

\begin{tabular}{|c|c|c|c|c|c|c|c|c|c|c|c|c|}
\hline $\begin{array}{l}\text { Isolate } \\
\text { No }\end{array}$ & $\begin{array}{l}\text { Myristic } \\
\text { acid } \\
\text { (\%) }\end{array}$ & $\begin{array}{l}\text { Pentadecanoic } \\
\text { acid }(\%)\end{array}$ & $\begin{array}{l}\text { Palmitic } \\
\text { acid (\%) }\end{array}$ & $\begin{array}{l}\text { palimitoleic } \\
\text { acid (\%) }\end{array}$ & $\begin{array}{l}\text { margaric } \\
\text { acid (\%) }\end{array}$ & $\begin{array}{l}\text { stearic } \\
\text { acid } \\
(\%)\end{array}$ & $\begin{array}{l}\text { oleic } \\
\text { acid } \\
(\%)\end{array}$ & $\begin{array}{l}\text { linoleic } \\
\text { acid } \\
\text { (\%) }\end{array}$ & $\begin{array}{l}\text { a- } \\
\text { linolenic } \\
\text { acid (\%) }\end{array}$ & $\begin{array}{l}\text { lignoseric } \\
\text { acid (\%) }\end{array}$ & $\begin{array}{l}\text { Total } \\
\text { unsaturated } \\
\text { fatty acids } \\
(\%)\end{array}$ & $\begin{array}{l}\text { Total } \\
\text { saturat } \\
\text { fatty } \\
\text { acids (? }\end{array}$ \\
\hline & C14:0 & C15:0 & C16:0 & C16:1 & C17:0 & C18:0 & C18:1 & C18:2 & C18:3 & C24:0 & & \\
\hline 1 & 0 & 0 & 11.95 & 0 & 0 & 36.82 & 17.51 & 33.72 & 0 & 0 & 51.23 & 48.77 \\
\hline 2 & 0 & 0 & 13.04 & 0 & 0 & 9.86 & 34.78 & 42.32 & 0 & 0 & 77.10 & 22.90 \\
\hline 3 & 0.07 & 0 & 10.20 & 0 & 0 & 3.33 & 37.82 & 48.26 & 0.23 & 0 & 86.30 & 13.60 \\
\hline 4 & 0.25 & 0.58 & 19.73 & 0 & 0.68 & 7.18 & 61.89 & 9.69 & 0 & 0 & 71.58 & 28.42 \\
\hline 5 & 0.34 & 0 & 15.41 & 0.73 & 0 & 5.71 & 46.16 & 29.27 & 0 & 1,71 & 76.16 & 23.17 \\
\hline 6 & 0.21 & 0 & 20.96 & 0 & 0 & 7.05 & 58.67 & 11.15 & 0 & 0 & 69.83 & 28.23 \\
\hline 7 & 1.03 & 0 & 55.86 & 0 & 0 & 20.76 & 14.84 & 5.00 & 0 & 0 & 14.84 & 82.65 \\
\hline 8 & 0.43 & 0 & 18.54 & 0.91 & 0 & 12.28 & 52.86 & 13.76 & 0 & 0 & 67.54 & 31.25 \\
\hline 9 & 0.23 & 0 & 9.76 & 0.99 & 0 & 5.98 & 36.71 & 44.40 & 0 & 1.83 & 82.09 & 17.80 \\
\hline 10 & 0.46 & 0 & 23.48 & 0.66 & 0 & 11.52 & 46.29 & 15.45 & 0 & 0 & 62.40 & 35.46 \\
\hline 11 & 0 & 0 & 33.91 & 0 & 0 & 13.77 & 13.88 & 38.44 & 0 & 0 & 52.32 & 47.68 \\
\hline 12 & 0 & 0 & 11.85 & 0 & 0 & 5.97 & 31.46 & 50.72 & 0 & 0 & 82.18 & 17.82 \\
\hline 16 & 0 & 0 & 12.38 & 0 & 0 & 5.02 & 47.81 & 34.56 & 0 & 0 & 82.37 & 17.39 \\
\hline 18 & 0 & 0 & 17.09 & 0 & 0 & 6.17 & 53.75 & 21.77 & 0 & 0 & 75.51 & 23.27 \\
\hline 26 & 0.15 & 0 & 10.33 & 0 & 0 & 3.48 & 34.04 & 51.71 & 0 & 0 & 85.75 & 13.95 \\
\hline 30 & 0 & 0.19 & 8.67 & 1.53 & 0.45 & 4.10 & 29.67 & 55.39 & 0 & 0 & 86.58 & 13.42 \\
\hline 41 & 0.25 & 0.30 & 12.96 & 0 & 0.40 & 5.52 & 40.65 & 39.33 & 0 & 0 & 79.97 & 19.43 \\
\hline 63 & 0.51 & 0.28 & 25.13 & 0.93 & 0.40 & 9.69 & 48.90 & 11.67 & 0 & 0 & 61.50 & 36.01 \\
\hline $68-2$ & 0.18 & 0 & 13.34 & 0 & 0 & 5.17 & 38.35 & 41.63 & 0,60 & 0 & 80.58 & 18.69 \\
\hline $68-1$ & 0.20 & 0.21 & 17.96 & 0 & 0.16 & 7.53 & 52.48 & 19.88 & 0 & 0 & 72.36 & 26.05 \\
\hline 82 & 0.27 & 0.21 & 19.63 & 0 & 0.21 & 8.41 & 58.54 & 10.69 & 0 & 0 & 69.23 & 28.74 \\
\hline 84 & 0.55 & 0.41 & 21.04 & 1.12 & 0.46 & 10.61 & 52.75 & 11.07 & 0 & 0 & 64.94 & 33.07 \\
\hline $95-1$ & 0.42 & 0 & 20.53 & 0.61 & 0 & 6.25 & 33.42 & 38.12 & 0 & 0 & 72.14 & 27.20 \\
\hline $95-2$ & 0.37 & 0 & 18.34 & 0 & 0 & 5.24 & 23.65 & 52.02 & 00 & 0 & 75.67 & 23.95 \\
\hline 110 & 0.23 & 0.42 & 14.65 & 0.24 & 0.57 & 5.90 & 51.36 & 25.95 & 0 & 0 & 77.55 & 21.77 \\
\hline
\end{tabular}

The predominant fatty acid in the lipid from isolate 1 that gave highest lipid content and highest lipid yield on crude glycerol was stearic acid (36,82\%) followed by linoleic acid (33.72\%), oleic acid (17.51\%), and palmitic acid (11.95\%). The results of fatty acid analysis after lipid production and optimization studies with Rhodotorula sp. [38], Psuedozyma sp. [1] were similar to ours. Areesirisuk et al. [1] were also remarked that these fatty acid profiles were the same as the vegetable oils used in biodiesel production and fatty acid profiles of some oleaginous yeasts, and also that the fatty acid composition used in biodiesel production affected biodiesel quality.

\section{Identification Of Oleaginous Yeasts}

The 25 oleaginous yeast isolates that selected by screening in the glycerol medium were identified by the molecular diagnosis methods based on sequencing of the ITS region of the rDNA and D1/D2 regions of 26 S of the rDNA. Results showed high sequence similarity (98-99\%) with strains in the GenBank. The 
GenBank accession numbers of the ITS and D1/D2 regions of strains sequenced in this study are given in Table 4.25 isolates were identified as 13 different strains (Table 4). Isolate 7 and 26 could not be identified, they might be new strains. Two of strains were reported for the first time as lipid- producing yeast, because no information on lipid production of Pichia cactophila and Clavispora lusitaniae was found in the literature. The results of this study have been shown that there were plentiful new microorganism resources which produce lipids by using glycerol as sole carbon source. 
Table 4

Identification results of 25 oleaginous yeasts.

\begin{tabular}{|c|c|c|c|}
\hline İsolate no. & Sequenced region & GenBank accession number & Species Name \\
\hline \multirow[t]{2}{*}{1} & ITS & MW493237 & \multirow[t]{2}{*}{ Pichia cactophila } \\
\hline & D1/D2 & MW487301 & \\
\hline \multirow[t]{2}{*}{2} & ITS & MW493238 & \multirow[t]{2}{*}{ Pichia fermentans } \\
\hline & D1/D2 & MW487302 & \\
\hline \multirow[t]{2}{*}{3} & ITS & MW493239 & \multirow[t]{2}{*}{ Rhodotorula mucilaginosa } \\
\hline & D1/D2 & MW487303 & \\
\hline \multirow[t]{2}{*}{4} & ITS & MW493240 & \multirow[t]{2}{*}{ Pichia fermentans } \\
\hline & D1/D2 & MW487304 & \\
\hline \multirow[t]{2}{*}{5} & ITS & MW493241 & \multirow[t]{2}{*}{ Pichia fermentans } \\
\hline & D1/D2 & MW487305 & \\
\hline \multirow[t]{2}{*}{6} & ITS & MW493242 & \multirow[t]{2}{*}{ Rhodotorula mucilaginosa } \\
\hline & D1/D2 & MW487306 & \\
\hline \multirow[t]{2}{*}{7} & ITS & \multirow[t]{2}{*}{ not identified } & \\
\hline & D1/D2 & & \\
\hline \multirow[t]{2}{*}{8} & ITS & MW493243 & \multirow[t]{2}{*}{ Clavispora lusitaniae } \\
\hline & D1/D2 & MW487307 & \\
\hline \multirow[t]{2}{*}{9} & ITS & MW493244 & \multirow[t]{2}{*}{ Saccharomyces cerevisiae } \\
\hline & D1/D2 & MW487308 & \\
\hline \multirow[t]{2}{*}{10} & ITS & MW493245 & \multirow[t]{2}{*}{ Wickerhamomyces anomalus } \\
\hline & D1/D2 & MW487309 & \\
\hline \multirow[t]{2}{*}{11} & ITS & MW493246 & \multirow[t]{2}{*}{ Rhodotorula mucilaginosa } \\
\hline & D1/D2 & MW487310 & \\
\hline \multirow[t]{2}{*}{12} & ITS & MW493247 & \multirow[t]{2}{*}{ Rhodotorula mucilaginosa } \\
\hline & D1/D2 & MW487311 & \\
\hline \multirow[t]{2}{*}{16} & ITS & MW493248 & \multirow[t]{2}{*}{ Candida glabrata } \\
\hline & D1/D2 & MW487312 & \\
\hline 18 & ITS & MW493249 & Pichia fermentans \\
\hline & D1/D2 & MW487313 & \\
\hline 26 & ITS & not identified & \\
\hline & D1/D2 & & \\
\hline 30 & ITS & MW493250 & Yarrowia lipolytica \\
\hline & $\mathrm{D} 1 / \mathrm{D} 2$ & MW487314 & \\
\hline 41 & ITS & MW493251 & Candida inconspicua \\
\hline & D1/D2 & MW487315 & \\
\hline 63 & ITS & MW493252 & Wickerhamomyces anomalus \\
\hline & D1/D2 & MW487316 & \\
\hline $68-1$ & ITS & MW493253 & Pichia fermentans \\
\hline & D1/D2 & MW487317 & \\
\hline $68-2$ & ITS & MW493254 & Pichia fermentans \\
\hline & D1/D2 & MW487318 & \\
\hline 82 & ITS & MW493255 & Pichia fermentans \\
\hline
\end{tabular}

Page 8/12 


\begin{tabular}{|c|c|c|c|}
\hline İsolate no. & Sequenced region & GenBank accession number & Species Name \\
\hline & D1/D2 & MW487319 & \\
\hline \multirow[t]{2}{*}{84} & ITS & MW493256 & \multirow[t]{2}{*}{ Rhodotorula mucilaginosa } \\
\hline & D1/D2 & MW487320 & \\
\hline \multirow[t]{2}{*}{$95-1$} & ITS & MW493257 & \multirow[t]{2}{*}{ Candida albicans } \\
\hline & D1/D2 & MW487321 & \\
\hline \multirow[t]{2}{*}{$95-2$} & ITS & MW493258 & \multirow[t]{2}{*}{ Pichia anomala } \\
\hline & D1/D2 & MW487322 & \\
\hline \multirow[t]{2}{*}{110} & ITS & MW493259 & \multirow[t]{2}{*}{ Candida inconspicua } \\
\hline & D1/D2 & MW487323 & \\
\hline
\end{tabular}

\section{Conclusion}

In this study two step screening was used for determining oleaginous yeasts which metabolize crude glycerol as the sole carbon source from newly isolated strains. The 25 tested strains were able to grow and consume the crude glycerol. Moreover, they were potentially lipid-producers and generating more than $25.55 \%$ (wt/wt) lipids. These results indicated the correctness of the screening process. Crude glycerol, a by-product of the biodiesel industry, was consumed mainly by Pichia cactophila (isolate 1), Rhodotorula mucilaginosa (isolate 6) and Pichia fermentans (isolate 4 and 18) showed the highest lipid production [more than 55\% (wt/wt)]. P. cactophila was showed the highest yield (64.94\%).

This is the first report of Pichia cactophila and Clavispora lusitaniae being categorized as an oleaginous yeast. Palmitic acid, stearic acid, oleic acid and linoleic acid, essential fatty acids for biodiesel production, were produced by all strains. Similar composition of fatty acids made it competitive with biodiesel production from other sources.

The screening, identification and characterization of potential productive oleaginous yeasts were the initial stage of microbial biodiesel production. All the results obtained from this study it was found that screening of new oleaginous microorganisms was important to find alternative sources of microorganisms to be used in biodiesel production and yeasts could be one of the most feasible and practicable sources for biodiesel production.

\section{Declarations}

\section{Acknowledgements}

This research was financially supported by the Anadolu University Scientific Research Projects Coordination Unit, Turkey (under grant number 1410F411).

\section{References}

1. Areesirisuk, A., Yen, T.B., Chiu, C.H., Liu, C.H., Guo, J.H.: Optimization on yeast lipid production of psuedozyma sp. with response surface methodology for biodiesel manufacturing. J. Adv. Agric. Technol. 2(1), 13-18 (2015). https://doi.org/10.12720/joaat.2.1.13-18

2. Easterling, E.R., French, W.T., Hemandez, R., Licha, M.: The effect of glycerol as a sole and secondary substrate on the growth and fatty acid composition of Rhodotorula glutinis. Bioresour. Technol. 100(1), 356-361 (2009). https://doi.org/10.1016/j.biortech.2008.05.030

3. Morita, T., Konishi, M., Fukuoka, T., Imura, T., Kitomato, D.: Microbial conversation of glycerol into glcolipid biosurfactants, mannosylerythritol lipids, by a basidiomycete yeast, Pseudozyma antarctica JCM 10317. Biosci. Bioeng. 104, 78-81 (2007). https://doi.org/10.1263/jbb.104.78

4. Li, C., Lesnik, K.L., Liu, H.: Microbial conversation of waste glycerol from biodiesel production into value-added products. Energies. 6, 4739-4768 (2013). https://doi.org/10.3390/en6094739

5. Taccari, M., Canonico, L., Comitini, F., Mannazzu, I., Ciani, M.: Screening of yeasts for growth on crude glycerol and optimization of biomass production. Bioresour. Technol. 110, 488-495 (2012). https://doi.org/10.1016/j.biortech.2012.01.109

6. Sriwongchai, S., Pokethitiyook, P., Kruatrachue, M., Bajwa, K.P., Lee, H.: Screening of selected oleaginous yeasts for lipid production from glycerol and some factors which affect lipid production by Yarrowia lipolytica strains. J. Microbiol., Biotechnol. Food Sci. 2(5), 2344-2348 (2013)

7. Hwangbo, M., Chu, K.H.: Recent advances in production and extraction of bacterial lipids for biofuel production. Sci. Total Environ. 734,139420 (2020). https://doi.org/10.1016/j.scitotenv.2020.139420

8. Thangavelu, K., Sundararaju, P., Srinivasan, N., Muniraj, I., Uthandi, S.: Simultaneous lipid production for biodiesel feedstock and decontamination of sago processing wastewater using Candida tropicalis ASY2. Biotechnol. Biofuels. 13(1), 1-14 (2020). https://doi.org/10.1186/s13068-020-01676-1

9. Li, W., Du, W., Li, Y.H., Liu, D.H., Zhao, Z.B.: Enzymatic transesterification of yeast oil for biodiesel fuel production. Chinese Journal of Process Engineering 7(4), 137-140 (2007)

10. Papanikolaou, S., Chatzifragkou, A., Fakas, S., Galiotoupanayotou, M., Komaitis, M., Nicaud, J., Aggelis, G.: Biosynthesis of lipids and organic acids by Yarrowia lipolytica strains cultivated on glucose. Eur. J. Lipid Sci. Techno. 111(12), 1-12 (2009). https://doi.org/10.1002/ejlt.200900055 
11. Ayadi, I., Kamoun, O., Trigui-Lahiani, H., Hdiji, A., Gargouri, A., Belghith, H., Guerfali, M.: Single cell oil production from a newly isolated Candida viswanathii YE4 and agro-industrial by-products valorization. J Ind Microbiol Biotechnol. 43, 901-914 (2016). https://doi.org/10.1007/s10295-016-1772-4

12. Arous, F., Azabou, S., Triantaphyllidou, I.-E., Aggelis, G., Jaouani, A., Nasri, M., Mechichi, T.: Newly isolated yeasts from Tunisian microhabitats: lipid accumulation and fatty acid composition. Eng. Life Sci. 17, 226-236 (2017). https://doi.org/10.1002/elsc.201500156

13. Maina, S., Pateraki, C., Kopsahelis, N., Paramithiotis, S., Drosinos, E.H., Papanikolaou, S., Koutinas, A.A.: Microbial oil production from various carbon sources by newly isolated oleaginous yeasts. Eng. Life Sci. 17, 333-344 (2017). https://doi.org/10.1002/elsc.201500153

14. Filippousi, R., Antoniou, D., Tryfinopoulou, P., Nisiotou, A.A., Nychas, G.J., Koutinas, A.A., Papanikolaou, S.: Isolation, identification and screening of yeasts towards their ability to assimilate biodiesel-derived crude glycerol: microbial production of polyols, endopolysaccharides and lipid. J. Appl. Microbiol. 127(4), 1080-1100 (2019). https://doi.org/10.1111/jam.14373

15. Uysal, ÜD., Öncü, E.M., Berikten, D., Yilmaz, N., Tuncel, N.B., Kıvanc, M., Tuncel, M.: Time and temperature dependent microbiological and mycotoxin (ochratoxin-A) levels in boza. Int. J. Food Microbiol. 130(1), 43-48 (2009). https://doi.org/10.1016/j.ijfoodmicro.2008.12.032

16. Kitcha, S., Cheirsilp, B.: Screening of oleaginous yeasts and optimization for lipid production using crude glycerol as carbon source. Energy Procedia. 9 , 274-282 (2011). https://doi.org/10.1016/j.egypro.2011.09.029

17. Pan, L.X., Yang, D.F., Shao, L., Li, W., Chen, G.G., Liang, Z.Q.: Isolation of the oleaginous yeasts from the soil and studies of their lipid producing capacities. Food Technol. Biotechnol. 47(2), 215-220 (2009)

18. Sluiter, A., Hames, B., Ruiz, R., Scarlata, C., Sluiter, J., Templeton, D.: Determination of sugars, byproducts, and degradation products in liquid fraction process samples.laboratory analytical procedure (LAP), Technical Report NREL/TP-510-42623 January: (2008)

19. Bozan, B., Temelli, F.: Supercritical $\mathrm{CO}_{2}$ extraction of flaxseed. J. Am. Oil Chem.' Soc 79(3), 231-235 (2002)

20. Maoura, N., Mbaiguinam, M., Nguyen, H.V., Gaillardin, C., Pourquie, J.: Identification and typing of the yeast strains isolated from bili bili, a traditional sorghum beer of chad. Afr. J. Biotechnol 4(7), 646-656 (2005)

21. White, T., Burns, T., Lee, S., Taylor, J.: Amplification and direct sequencing of fungal ribosomal RNA genes for phylogenetics. In: Innis, M.A., Gelfand, D.H., Sninsky, J.J., White, T.K. (eds.) PCR Protocols: A Guide to Methods and Applications, pp. 315-322. Academic Press, London (1990)

22. Dobrowolski, A., Drzymała, K., Rzechonek, D.A., Mituła, P., Mironczuk, A.M.: Lipid Production From Waste Materials in Seawater-Based Medium by the Yeast Yarrowia lipolytica. Front. Microbiol. 10, 547 (2019). https://doi.org/10.3389/fmicb.2019.00547

23. Rakicka, M., Lazar, Z., Patrick, T.D. F., and Jean Marc, N.: Lipid production by the oleaginous yeast Yarrowia lipolytica using industrial by-products under different culture conditions. Biotechnol. Biofuels. 8, 104 (2015). https://doi.org/10.1186/s13068-015-0286-z

24. Kosamia, N.M., Samavi, M., Uprety, B.K., Rakshit, S.K.: Valorization of biodiesel byproduct crude glycerol for the production of bioenergy and biochemicals. Catalysts. 10(6), 609 (2020). https://doi.org/10.3390/catal10060609

25. Kumar, L.R., Yellapu, S.K., Tyagi, R.D., Drogui, P.: Microbial lipid and biodiesel production from municipal sludge fortified with crude glycerol medium using pH-based fed-batch strategy. J.Environ. Chem. Eng. 105032. (2021). https://doi.org/10.1016/j.jece.2021.105032

26. Neto, C.D., Sydney, E.B., Candeo, E.S., de Souza, E.B.S., Camargo, D., Sydney, A.C.N., ... Soccol, C.R.: New Method for the Extraction of Single-Cell Oils from Wet Oleaginous Microbial Biomass: Efficiency, Oil Characterisation and Energy Assessment. Waste Biomass Valor. 11, 3443-3452 (2020). https://doi.org/10.1007/s12649-019-00705-x

27. Papanikolaou, S., Aggelis, G.: Modelling lipid accumulation and degredation in Yarrowia lipolytica cultivated on industrial fats. Curr. Microbiol. 46, 398402 (2003). https://doi.org/10.1007/s00284-002-3907-2

28. Robles-Rodríguez, C.E., Muñoz-Tamayo, R., Bideaux, C., Gorret, N., Guillouet, S.E., Molina-Jouve, C., Roux, G., Aceves-Lara, C.A.: Modeling and optimization of lipid accumulation by Yarrowia lipolytica from glucose under nitrogen depletion conditions. Biotechnol. Bioeng. 115(5), 1137-1151 (2018). https://doi.org/10.1002/bit.26537

29. Beopoulos, A., Cescut, J., Haddouche, R., Uribelarrea, J.L., Molina-Jouve, C., Nicaud, J.M.: Yarrowia lipolytica as a model for bio-oil production. Prog. Lipid Res. 48, 375-387: (2009). https://doi.org/10.1016/j.plipres.2009.08.005

30. Sestric, R., Munch, G., Cicek, N., Sparling, R., Levin, D.B.: Growth and neutral lipid synthesis by Yarrowia lipolytica on various carbon substrates under nutrient-sufficient and nutrient-limited conditions. Bioresour. Technol. 164, 41-46 (2014). https://doi.org/10.1016/j.biortech.2014.04.016

31. Leiva-Candia, D.E., Tsakona, S., Kopsahelis, N., Garcia, I.L., Papanikolaou, S., Dorado, M.P., Koutinas, A.A.: Biorefining of by-product streams from sunflower-based biodiesel production plants for integrated synthesis of microbial oil and value-added co-products. Bioresour. Technol. 190, 57-65 (2015). https://doi.org/10.1016/j.biortech.2015.03.114

32. Kitcha, S., Cheirsilp, B.: Enhancing lipid production from crude glycerol by newly isolated oleaginous yeasts: strain selection, process optimization, and fed-batch strategy. Bioenergy Res. 6, 300-310 (2013). https://doi.org/10.1007/s12155-012-9257-4

33. Saenge, C., Cheirsilp, B., Suksaroge, T.T., Bourtoom, T.: Potential use of oleaginous red yeast Rhodotorula glutinis for the bioconversion of crude glycerol from biodiesel plant to lipids and carotenoids. Process Biochem. 46, 210-218 (2011). https://doi.org/10.1016/j.procbio.2010.08.009

34. Fakas, S., Papanikolaou, S., Batsos, A., Galiotou-Panayotou, M., Mallouchos, A., Aggelis, G.: Evaluating renewable carbon sources as substrates for single cell oil production by Cunninghamella echinulata and Mortierella isabellina. Biomass Bioenergy. 33, 573-580 (2009).

https://doi.org/10.1016/j.biombioe.2008.09.006

35. Liu, L., Hu, Y., Lou, W., Li, N., Wu, H., Zong, M.: Use of crude glycerol as sole carbon source for microbial lipid production by oleaginous yeasts. Appl. Biochem. Biotechnol. 182, 495-510 (2017). https://doi.org/10.1007/s12010-016-2340-0

36. Mast, B., Zöhrens, N., Schmidl, F., Hernandez, R., French, W. T., Merkt, N., ... Graeff-Hönninger,S. Lipid production for microbial biodiesel by the oleagenious yeast Rhodotorula glutinis using hydrolysates of wheat straw and miscanthus as carbon sources. Waste Biomass Valori 5(6), 955-962 (2014). 
https://doi.org/10.1007/s12649-014-9312-9

37. Knothe, G.: Improving biodiesel fuel properties by modifying fatty ester composition. Energ. Environ. Sci. 2(7), $759-766$ (2009).

https://doi.org/10.1039/B903941D

38. Bandhu, S., Dasgupta, D., Akhter, J., Kanaujia, P., Suman, S.K., Agrawal, D., Kaul, S., Adhikari, D.K., Ghosh, D.: Statistical design and optimization of single cell oil production from sugarcane bagasse hydrolysate by an oleaginous yeast Rhodotorula sp. IIP-33 using response surface methodology. Springer Plus. 3, 691 (2014). https://doi.org/10.1186/2193-1801-3-691

\section{Figures}

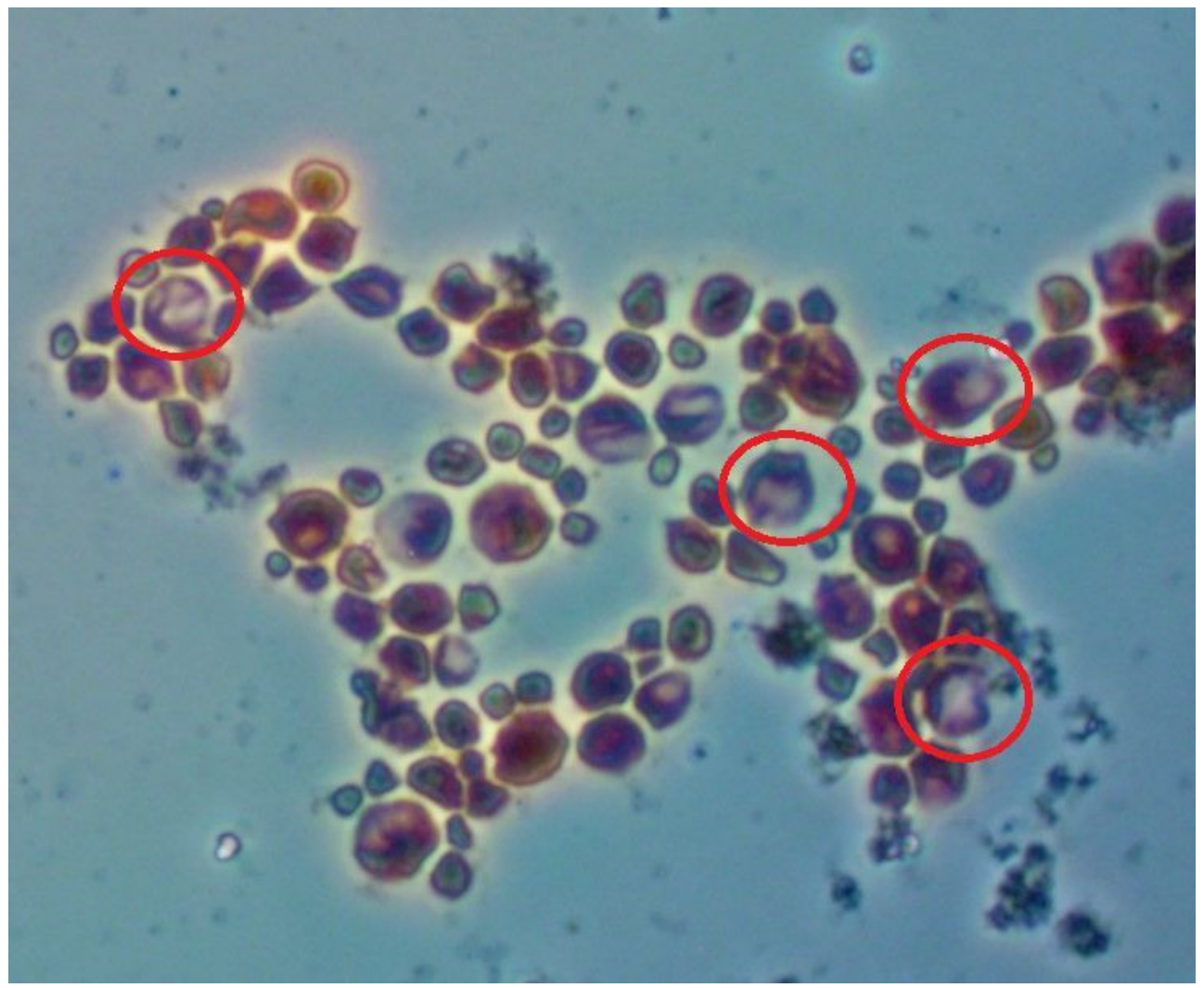

\section{Figure 1}

Ninety-two strains which could be growing both of the medium or only crude glycerol medium were stained with Sudan black B technique and observed under microscope for the presence of fat globules within the cell. Sixty yeast strains were found positive for showing fat globules within the cell 


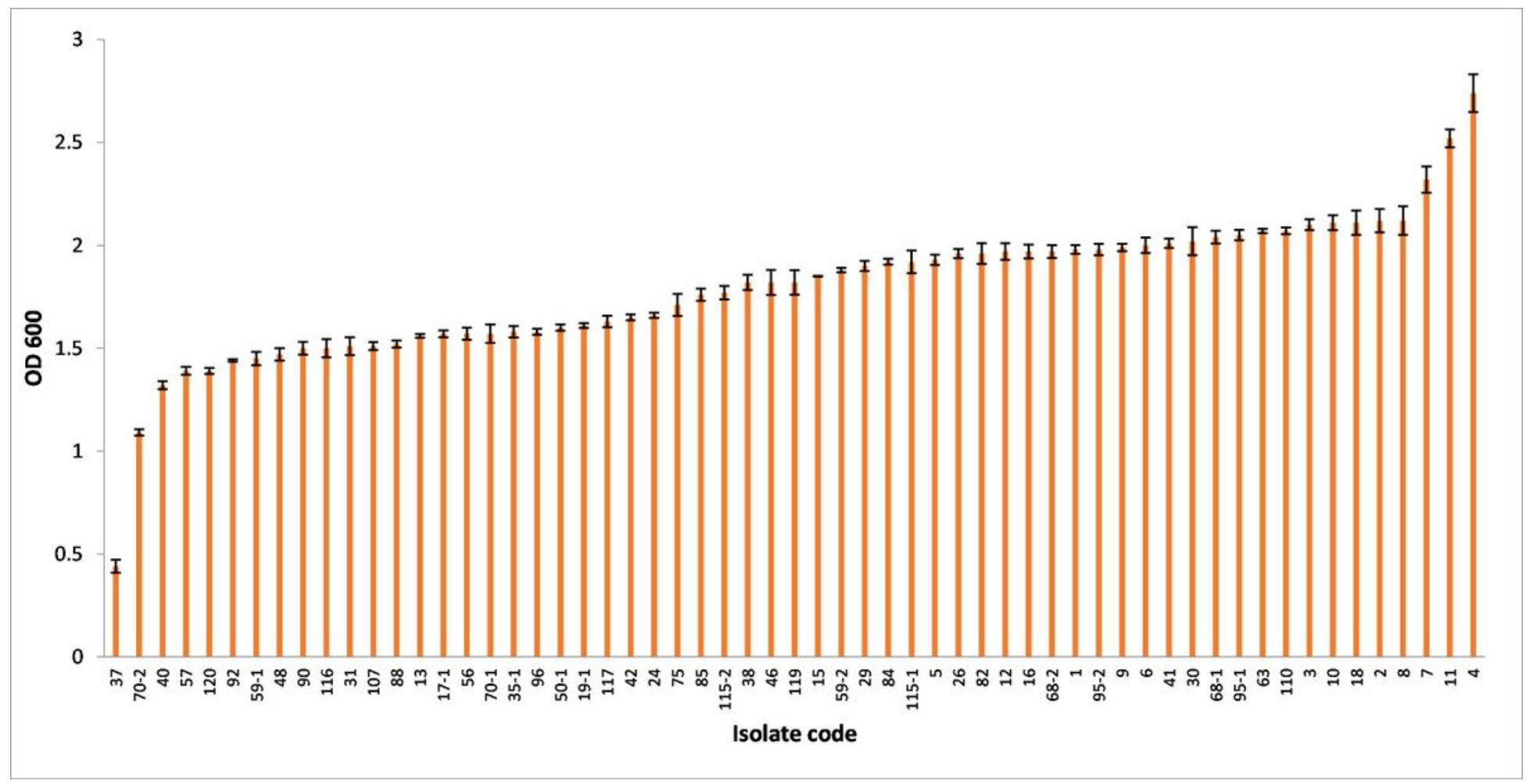

Figure 2

Between the 60 yeast strains tested, 25 grew well and reached final OD600 of nearly 2 Units or up. They were selected for calculation of growth parameters and lipid yield. Good performance was exhibited by isolate 4 that reached final OD600 of 2.74 on the other hand isolate 37 grew most poorly

\section{Supplementary Files}

This is a list of supplementary files associated with this preprint. Click to download.

- graphicalabstract.tif 